Università degli Studi di Genova

DISEFIN - Series of Economic Working Papers

16126 Genova - via vivaldi 5 - Fax +39010 2095223

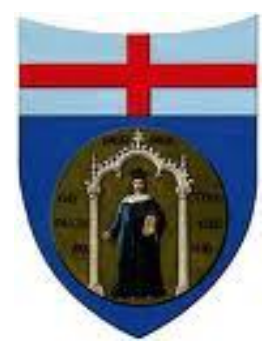

Vilfredo Pareto and the methodology of the Italian tradition in public finance

Amedeo Fossati

wp n. 1

AUGUST 2010 
"DISEFIN Working Papers on line"

series of economic working papers

published online by

Research Doctorate in

Economics and Finance of European Union

Ph.D School in New technologies and Social Sciences

University of Genoa

Founder:

Amedeo Fossati

Editor-in-Chief:

Marcello Montefiori

Editorial Board:

Paul De Grawe

Francesco Figari

Amedeo Fossati

Luca Gandullia

Eric Gaspérini

Andrea Monticini

Carlo Perroni

\section{Web site:}

http://www.disefin.unige.it/ 


\title{
Vilfredo Pareto and the methodology of the Italian tradition in public finance
}

\author{
Amedeo Fossati \\ University of Genoa \\ Italy
}

\begin{abstract}
A bstract
In the last decade of the nineteenth century, Italian scholars started using a scientific methodology to tackle public finance problems. Their studies are now referred to as the Italian tradition in public finance, whose origin is considered to lie with De Viti de Marco (1888). Shortly before his death in 1950, Fasiani, the last scholar of the Italian tradition, published an important article, in which he showed that, even if Pareto never worked in public finance, he had some influence on the Italian public finance scholars. This paper aims to draw scholarly attention to the above article and to direct new light onto Pareto's methodol ogical influence on the Italian tradition. Firstly it is pointed out that the Paretian idea of science deeply influenced the late scholars of the Italian tradition. Secondly, it is shown that Paretian sociology was less important than his economic methodology. Thirdly, it is argued that it is necessary to distinguish the problems concerning the explanation of public choices, from the problems of the economic effects of public policies, then, in a generalized Paretian approach, most public policies may be studied under economic hypothesis. It follows that much of the Italian tradition may be taken back to a Paretian approach, even if it remains true that, in the latter, public choices may be explained by sociological reasoning only.
\end{abstract}

Keywords: Vilfredo Pareto, Italian tradition in public finance Jel Classification: B00, B30, B4 


\section{Introduction}

A few months before his death in 1950, Mauro Fasiani, who is here considered the last scholar of the Italian tradition, published his last important article entitled Pareto's contributions to Public Finance (Fasiani, 1949) which has recently been translated into English $^{1}$. Fasiani's main contribution is to have shown that even if Pareto never worked in public finance, and had quite a low consideration for such studies, nonetheless he had an important and manifold influence on the Italian public finance scholars. Thus, this paper primarily aims to draw scholarly attention to the above article and at the same time, building on Fasiani's contribution, to direct new light onto Pareto's methodological influence on the Italian tradition in Public Finance. In fact, sixty years have elapsed, facts and theories have evolved and interests have changed, but Pareto and the Italian tradition are still considered important. However, they could be perceived in a rather different perspective, hence it now seems worth revisiting them ${ }^{2}$.

For a scientific theory of public finance, the crucial problem was to explain why in a certain economic system, at a certain time, public intervention assumes that specific structure ${ }^{3}$. Italian scholars were the first to use a scientific methodology to tackle such a problem. In the last decade of the nineteenth century and up to the period between the two World Wars, Italian public finance scholars ranked at the top of the international scene, although they were largely ignored and rediscovered in the sixties by Buchanan. In

\footnotetext{
${ }^{1}$ It has been included among other important articles published in the Giornale degli Economisti between 1915 and 1949, in the excellent book by McLure (2007). In this paper, quotations are taken from that translation.

${ }^{2}$ Some traces may be found in Da Empoli (2001); unfortunately, the occasional character of that writing did not allow him to thoroughly analyse the topic.

${ }^{3}$ Italian tradition followed mainly the positive approach, considered a logical prius with respect to the normative approach. The other problems may be labelled as the study of the effects of public actions.
} 
general, their studies are now referred to as the Italian tradition in public finance, whose origin is usually considered to lie with De Viti de Marco (1888).

In that seminal study, De Viti proposed a scientific explanation of public intervention in the economy since he used the methodology which at the time was spreading in economics, i.e., marginal analysis. In other words, he used the same explaining principles as are used in economics, in particular the maximizing assumption for the economic agents; moreover, the proposed explanation was explicitly founded on the hypothesis that public action had not only economic effects but also a basic economic nature.

The last decade of the nineteenth century, however, was the time when Pareto started working, firstly in economics and then in sociology. In point of fact, until his death in Céligny in 1923, he was the most important Italian economic theorist, even though he was never part of the Italian academy ${ }^{4}$. Pareto's scientific interests did not concern public finance, and he had nothing to do with the Italian tradition, excepting some harsh judgements on its scientific character. His main point is that public intervention is essentially sociological in character, and cannot be studied with an economic methodology. Nonetheless, he had a large influence on the Italian tradition through his economic and sociological methodology.

According to Fasiani, Pareto's main influence was through his sociological approach, but as is shown in section 2 of this paper, he mainly discusses his general scientific methodology. The fact is that many scholars still considered value judgments and ethical principles an important part of their scientific approach.

\footnotetext{
4 "I don't really care that they didn't want me to teach Political Economy in Italy" (Pareto, letter to Sensini dated December 8th, 1904: Sensini, 1948, p.3).
} 
Concerning the Paretian methodology as was applied to the study of public finance, in this paper three points are raised. Firstly, it is pointed out that the Paretian idea of science deeply influenced the late scholars of the Italian tradition. Secondly, it is highlighted that, owing to an obviously myopic perspective, Fasiani was unable to realize that Paretian sociology was less important than Paretian revolution in the economic methodology. Thirdly, it is argued that it is necessary to distinguish two different kinds of problems; the first concerns the explanation of public choices, the second is interested in the economic effects of public policies. Then, in this paper it is argued that in a generalized Paretian approach the effects of most public policies may be studied assuming economic hypothesis as a first approximation, even if it remains true that public choices may be explained by sociological reasoning only. Thus it is stated here that much of the Italian tradition may be taken back to a Paretian approach .

The paper is organized as follows: in section 2, attention is focused on the few statements and suggestions that Pareto directed towards public finance. Section 3 is devoted to illustrating Pareto's essential contributions to economics and sociology that have influenced the methodology of the Italian tradition. Section 4 and 5 respectively consider how Pareto's sociological and economic methodology had influenced the Italian tradition; the last section presents some final remarks.

\section{Pareto's statements and suggestions concerning Public Finance}

${ }^{5}$ For a more detailed discussion about the specific involvement of the single scholars with Pareto's methodology, see Fossati (2009). 
Pareto considered public intervention in the economic system as facts ${ }^{6}$, which of necessity had to be included in the equations that define general economic equilibrium: "Such remarks are to be made for the salary of the ever growing bureaucracy of modern States; for war expenditure, for the navy and for a large part of public works. Here, the ultimate concern is not whether (or how) such expenses are useful to the community, or even, in some cases, necessary: the point is simply that their kind of utility is different from the utility directly connected to economic production...The part taken by the public authority is spent according to different criteria, which are not to be investigated by the economic science. Thus, the latter has to assume that they appear among the data of the problem to be solved" (Pareto, Manuale, Chap.VI, n. 27 and 30, p. 252).

Thus, in his opinion, the task of explaining the public choices had to be left to sociology: for this reason, he never considered studying public finance. The fact is that Pareto's critiques to the scienza delle finanze (Pareto, Trattato di sociologia, II, pp. 642-47, $\S \S 2270-3)$ are based on his firm opinion that the actions of the governing elites are in large part non-logical ${ }^{7}$. For him, economic theory deals with logical actions only: it follows that the scienza delle finanze, which is only a collection of derivations, cannot use economic methodologies. In particular, marginal analysis cannot be used to determine public goods equilibrium, as Italian tradition was suggesting. "To us the defect [of treating everyone as a perfect hedonist] ...seems most serious when one wants to turn the principles of the new science to studies of phenomena that are not exclusively economic. As an example, the science of public finance, in many cases, and governments, in nearly all cases, fall

\footnotetext{
${ }^{6}$ See D'Albergo (1952, p. 40).

${ }^{7}$ For the Paretian meaning of non-logical actions, derivations and residues see below, end of section 3
} 
into gross errors. When these are combined with postulates of the kind that concern the character of State ethics...they become like fairy tales" (Pareto, 1892, quoted by McLure, 2007, p. 120).

It is true that the notion of public need plays a great role in the Paretian circulation of elites; nevertheless it cannot be used to determine economic equilibrium, on two grounds. Firstly, it is a derivation, and thus it cannot be satisfied by logical actions; secondly, it is undetermined. In fact, Pareto observes that it may alternatively be intended as: (i) a real need for everybody; (ii) a real need for someone; (iii) a need that a majority has declared a public need; (iv) a need that has been declared public by a majority of an assembly, or by groups which are given authority by that assembly, or which has gained authority through cunning or force (Pareto, Trattato di sociologia, II, pp. 645, § 2272; Fasiani, 1949, p. 294). In conclusion, for Pareto, public finance cannot be investigated by theoretical economics, but by sociology.

Thus it is not surprising that Pareto expressed extremely negative judgements regarding the scienza delle finanze and its scholars, principally in the Trattato di sociologia, and then in his correspondence (Pareto's letters to Griziotti and Sensini in particular). There are no possible doubts that such harsh judgements are directed to the Italian tradition in public finance, because they were all expressed later than 1888 , i.e., the date of the foundation of scientific scienza delle finanze.

In his letters to Griziotti, Pareto reiterates that no taxpayer makes difficult calculations, that the state is simply a metaphysical entity and that public needs do not exist. Besides, we are not able to ascertain how economic and sociological equilibria are modified by public economic interventions; the fact is, while we know a little about the economic equilibria, we do not know anything about the sociological ones (Griziotti, 1943). However, the correspondence 
with Griziotti primarily addresses the public debt problem, originating from a letter asking Pareto's opinion about his own analysis of the Ricardian problem of the different effects of debt and extraordinary tax. Thus, the letters confirm firstly that Pareto did not consider the problem of the debt/taxation burden important, because it is the redistributive effect that really matters. Secondly, they highlight his belief that the analysis of comparative effects of taxation and public debt should be mainly based on their sociological aspects. In fact, the choice between public debt and taxation depends not upon their relative burdens, but in accordance with some position of the sociological equilibrium. In $\$ 2306$ of Trattato di sociologia, public debt is considered to be simply a case of income transfer from the class of the réntiers to the other classes. According to Fasiani, however, some hints indicate that Pareto considered it possible to transfer the burden of public debt to future generations (Fasiani, 1949, p. 277).

The letters to Sensini confirm the harsh judgements already mentioned: suffice it to recall that on April 9th 1905 he wrote about the scienza delle finanze: "they call it a science, but it is not even an art", and about public finance treatises: "with regard to the scientific theories, the best of them are worth just about zero". However, in that letter, Pareto encouraged Sensini to start studying public finance because "in that field, everything is yet to be done" (Sensini, 1948, p.7) and again, on April 5th 1917, he wrote: "I would say it is good for you to publish a book about the scienza delle finanze, as you are telling me" (Sensini, 1948, pp. 100-101)

In the above mentioned 1905 letter, Pareto gave to Sensini two important technical suggestions concerning how research in public finance could be carried out: the first is to make a distinction between pure science and the analysis of real phenomena. As for the latter, the suggestion is "to look out for uniformities, which can be helpful for the pure science"; the second suggestion concerns 
non-logical actions. In fact, "the tax-payer is not aware... of many effects of the taxes... His actions, therefore, are not of the logical type, with which political economy deals, and whose theory is less difficult; they are instead actions of the non-logical type, whose theory is far more difficult" (Sensini, 1948, p. 7, quoted in Fasiani 1949, p. 290).

De Pietri-Tonelli, Borgatta, Sensini and Fasiani believe that Pareto has shown the scienza delle finanze a new course, characterized by an extremely important structural design. What they have in mind is the extension of the methodology of sociology to public finance; this, however, is the topic of section 4 .

\section{An outline of Pareto's methodological contributions that influenced Italian scholars ${ }^{8}$}

The first methodological point that influenced Italian public finance scholars is Pareto's general scientific approach; this fact was acknowledged by Fasiani, who devoted ten out of the thirtyone sections of his article to the Paretian general scientific methodology?

Pareto defined his idea of science as logico-experimental, since he founded it on the study of facts; he believed that the only criterion for evaluating a theory was its compliance with the facts. He believed that reasoning based on assumptions could only result in approximations of reality, which can be improved by successive approximations. The latter, however, can be asymptotic only in

\footnotetext{
${ }^{8}$ For an exposition of the Paretian methodology, see McLure (2007), Chapter 3 in particular.

${ }^{9}$ That is to say the whole heading "The second group including the treatment of methodological problems". It is true that, apparently, the heading is devoted to the methodology of the social sciences, however, most of those sections concern the general methodology of the science.
} 
pure economics and not in the social sciences, to which - according to Pareto - public finance belongs.

For him, the first rule for a logico-experimental science should be the elimination of preconceptions, prejudices, judgements of good and evil, moral sentiments. In the logicoexperimental theories, the principles are abstract postulates, accepted as hypotheses to the extent that they comply with the facts. On the contrary, in the non logico-experimental theories we find "scattered principles that are accepted a priori, independently from experience, which they dominate. They do not depend on the facts, but the facts depend on them" (Pareto, Trattato di sociologia, quoted in Fasiani, 1949, p. 286). In short, Pareto's methodology calls for clear principles, related to facts, while any value judgement may concern only the aptitude of the means to reach a proposed end ${ }^{10}$.

The point at issue was important to Fasiani since some Italian public finance scholars did not consider it so obvious to exclude from the theoretical construction all preceptive propositions, categorical imperatives, consequences drawn from arbitrary principles (Fasiani, 1949, p. 280) ${ }^{11}$. From that angle, it is remarkable that this Paretian message was quite at odds with a large part of the Italian tradition which believed, together with Einaudi, albeit with some ambiguities, that moral values could influence scientific reasoning; in fact in Einaudi (1943a) we can find a bold and passionate defence of value judgements in the social sciences. On the other hand, this Paretian message was

\footnotetext{
${ }^{10}$ As recalled above, Fasiani apparently discusses the methodology of social sciences (and thus of sociology, of which public finance is a branch according to Pareto), but in actual fact, such a discussion concerns the whole Paretian research programme, and is not peculiar to the social sciences.

${ }^{11}$ Fasiani is quoting Borgatta: it is Pareto's obituary, published in La Riforma sociale, 1923, September-October, pp. 385-403.
} 
accepted totally by Fasiani ${ }^{12}$, and remains one of the principal lessons that the late Italian public finance scholars had taken from Pareto $^{13}$.

A second methodological point that influenced public finance scholars is the idea of the general economic equilibrium, which was altogether crucial in Pareto. In fact, in a letter dated August 8th 1911 to Sensini (Sensini, 1948, p. 61), he said: "I was induced to study theoretical and mathematical economics from the reading of Pantaleoni's Principii. Before that, I started with Walras' works, but their large metaphysical part disgusted me, so that I didn't bother to go on reading. Pantaleoni's Principii convinced me that pure economics offers things other than metaphysics. Reading Walras' works again, paying no attention to his metaphysics, considering them as not having been written, I realized that there was there a very important theory, that is to say the theory of the general economic equilibrium". Thus, he soon abandoned the approach of his friend Pantaleoni, because he turned to the Walrasian economic equilibrium scenario. However, while considering Walrasian market interdependences as crucial, he always refused Walras' scientific approach, considering it to be mixed with normative statements and arbitrary principles ${ }^{14}$. For example, on February 16th 1911, he wrote: "Walras' works in Social economics have no value at all: they are just thaumaturgists' chitchat" (Sensini, 1948, p. 56).

It is a fact that Pareto's first scientific interests concerned rewriting and extending general economic equilibrium: the main reference for this work is the Cours d'Économie politique (1896-

\footnotetext{
${ }^{12}$ The question of value judgements in social sciences had been the subject of a heated debate between Fasiani and Einaudi: see Fossati, (2009).

${ }^{13}$ The opportunity to distinguish economic theory from value judgements and politics was stated in the thirties by Robbins (1932) and Myrdal (1932).

${ }^{14}$ For the main points of divergence from Walras' economics, see the letter to Pantaleoni dated December 19th 1908 in De Rosa (1960, III, p.121).
} 
97). Paretian general economic equilibrium is basically Walrasian, where disturbances (due to errors of evaluation by economic agents) cause fluctuations around a moving equilibrium point. Here, in what Pareto considered "pure theory", he introduced the distinction between utility and ophelimity, and extended the general equilibrium to the monopoly case, since Walras had considered perfect competition only. Besides, he defined money as a means of exchange only, and finally introduced the idea of successive approximations. In his idea of applied economics, Pareto contributed to the theory of rent (which was perfected by Sensini); introduced, in the general equilibrium, variable coefficients of production (instead of Walrasian fixed coefficients); presented the theory of international trade; and finally, presented his law of income distribution.

A third point that influenced public finance scholars is represented by Pareto's contributions to the economic methodology presented in the Manuale (1906) and in its French version Manuel (1909). On the one hand it is the choice theory, i.e., the new specification of the theory of general equilibrium in terms of tastes and obstacles, and on the other hand, the concept of ordinal utility, derived not from an aprioristic hedonistic function, but from observing consumers' actual choices: Samuelson later called it the revealed preference approach. Finally, we have the first formulation of the idea of economic efficiency, and thus of the theorems of welfare economics.

Not only the economic, but also the sociological Paretian methodology had a deep influence in Italian public finance studies. The main idea of Pareto's sociological approach is that human actions are not motivated by pure logic, but in large measure by sentiments. Thus, he developed his elites theory and the concepts of logical and non-logical actions; even though many points are anticipated in the Manuale, for the Paretian sociology the first 
representative work is Les Systèmes Socialistes (1902-1903). His general theory of sociological equilibrium, which in his approach comprises the economic equilibrium, was developed in the Trattato di sociologia (1916), even if the crucial dichotomy "maximum of the community" and "maximum for the community" was set forth in Pareto's 1913 work. Certainly, it is not possible here to discuss Paretian sociology; for the understanding of the following sections it seems important, however, to recall at least the crucial notions of logical and non-logical actions, and of residues and derivations.

In logical action, there is always a logical objective end (the result of the action) which is identical to the subjective end. In the non-logical action, there may be no objective or subjective end (or neither); however, if both ends exist, they are different ${ }^{15}$. The importance of this notion is that economics deals mainly in logical actions, while non-logical actions cannot be examined under economic assumptions.

As for residues and derivations, Pareto points out that in beliefs, theories or real phenomena, two elements may be distinguished. The first element is the main or substantial part - the residue; the second one is an accidental one, which is variable - the derivation. The residue corresponds to non-logical actions directly and it is the expression of one or more sentiments: it is the principle that exists in the minds of men. The derivation is the expression of man's need for logic; it consists in the explanations of the residue, i.e., in the logical or pseudo-logical reasoning which serves to justify the residue. For example, the idea of public need is a typical derivation: the governing elites pretend that the goods, which are

\footnotetext{
${ }^{15}$ In competitive markets, the entrepreneurs carry out in part non-logical actions, because their (subjective) end is profit, while the result is economic efficiency (objective end). On the other hand, such actions become logical actions in monopoly markets.
} 
useful for them but paid for by the people, are selected because they satisfy a "public need".

Finally, I would like to draw attention to the outcomes of the Paretian notions of the "maximum of the community" and "maximum for the community", on which Fasiani founded the definition of his polar cases of Tutorial and of Cooperative State respectively, as will be discussed below. The "maximum for" regards ophelimity, concerns economics only, and in point of fact it is simply the "Pareto optimum". The "maximum of" is sociological, may involve either utility or ophelimity, and implies value judgements about the welfare of the single individuals. General public finance theory is necessarily concerned with public choices, and thus it seems that the idea of a maximum referred to the community is quite relevant. On that point Pareto's analysis is much more advanced than the previous Pantaleoni's hedonistic maximum.

\section{The influence of Paretian sociological methodology}

Regarding public finance specifically, Fasiani argues that the suggestions, the critiques and the hints that appear here and there, both in Pareto's works and in his letters, show that he could not even conceive of a methodological problem regarding the scienza delle finanze because, for him, the methodology of social sciences had to be used. The Paretian message is clear: public finance theory, intended as a logico-experimental science, cannot help using the methodology of social sciences, i.e., the methodology of sociology.

Pareto's point of view that public choices should be studied with sociological methodologies might be convincing, but the fact remains that he left his sociology at an initial and not very helpful stage. The methodology was still to be worked out in great part, so 
that a large undertaking was awaiting those who wanted to venture along a path which had not existed so far: in fact, Pareto warned that the theory of the sociological equilibria is much more difficult than the theory of economic equilibria.

The point is that Pareto's sociology was not able to provide far-reaching methodological tools to explain non-logical actions both of the governing elites and of the taxpayers, because Pareto only left generic suggestions. The heart of the matter can be summarised fairly briefly, because the only specific methodological lesson that can be drawn from Pareto is that public finance concerns largely non-logical actions. Thus, every explanation depends on the construction of a theoretical representation of nonlogical human actions. In Fasiani's words, Pareto's only suggestion is to single out "the relationships of interdependence that exist between residues, interests, derivations and circulations of the élites" (Fasiani, 1949, p. 291).

Borgatta and Sensini were the only two scholars that tried to build a scienza delle finanze following Pareto's methodological suggestions, and thus they were considered as the founders of a "sociological school", which remained, however, at an initial stage $^{16}$. Their common faith was that in public finance non-logical actions are the crucial building block, and both of them started setting up their own foundation of the new sociological scienza delle finanze. They succeeded in providing a general framework only, in which the public finance problems were positioned in a sociological perspective, problems that, however, were still looking forward to their solutions. The sociological school is "terrific in its destructive critique of the hedonistic and logico-political theories,

\footnotetext{
${ }^{16}$ Borgatta, 1912 and 1920; Sensini, 1917 and 1920. For a more detailed description of the Sensini and Borgatta framework, see Fasiani (1932-33) and Fossati (2009).
} 
attractive for some suggestions and some aspects of its analysis, [but] seems really unable to formulate a really intrinsic law concerning public finance" (Fasiani, 1932-33, II, p.106). In conclusion, their results were very modest, as their ingenuity was not matched by the theoretical corpus of the Paretian sociology that was still lacking.

If this had been the whole story, the conclusion would be that, in the Italian tradition, Pareto's approach played the relatively small role of criticizing the hedonistic approach, and offered no real heuristic contribution. However, much of Borgatta's and some of Sensini's research, apart from general theorizing, was geared to more concrete public finance topics, where they used economic methodologies. Such research might seem at odds with the Paretian approach, highlighting an internal contradiction in the sociological school.

However, it is possible to show that the above mentioned contradiction is not factual. According to Pareto, there is no doubt that the public finance problems pertaining to public choices can be considered using sociological constructs only. His main opposition to a theoretical science of public finance is that a large part of its problems regard non-logical actions, i.e., are sociological problems. That is to say, Pareto opposed in particular a science that aimed to explain public actions by economic assumptions and reasoning only - such as that of De Viti. I would say, however, that there is a second reason why the scienza delle finanze did not exist for Pareto: some public finance problems, by mere definition, are applied economic problems, and it is not necessary to distinguish them from other applied economic problems. As stated above at the beginning of section 2, Pareto considered public economic activity as facts, to be necessarily included in the equilibrium equations. It follows that if - for example - the State modifies the income tax rate, the point of equilibrium changes, and the changes can be taken 
as the effects of the change in taxation. Pareto would not consider such analysis under the label of "pure economics", but rather under that of "applied economics". Thus, my point is that in a strict Paretian approach some public finance problems may be considered, albeit under the label of applied economics.

This reasoning enables us to give inner coherence to the economic studies performed by the sociological approach, and to acknowledge a Paretian mark even in the case of other scholars usually not considered part of the sociological school, for example, Barone and Fasiani. In other words, it allows a large part of the specific studies of the Italian tradition to be considered under a Paretian cover, even if the remaining efforts to explain public choices by economic or political assumptions remain under Pareto's anathema.

In point of fact, it seems that Borgatta was aware of such a problem of coherence that he probably considered resolved by his distinction between "sociological problems and financial economic problems". In the former problems, the financial phenomenon is "essentially sociological and as such its uniformities cannot be investigated basing them on pure economic assumptions, nor treating them as a system of logical actions". In the "financial economic problems", in general "it is not sufficient to use pure economic assumptions to deduce financial uniformities; in fact, for many problems, one must consider the sociological processes that are necessarily connected" (Borgatta, 1920, p. 6). Now Borgatta does not say "for all the problems" but "for many problems", hence it follows that for "some" financial economic problems, sociological processes are not particularly relevant. In those cases, albeit in a first approximation, the analysis may be based on pure 
economic assumptions ${ }^{17}$, but this statement seems necessarily founded on the reasoning I suggested above that such problems are really applied economic problems.

Borgatta, however, also said: "I confess that I find - I would say much too rigorous the pages that Pareto devoted to the scienza delle finanze...Pareto only considers the preceptive aspects, the character of derivations of its propositions, leaving aside and denying the contents of scientific attempts that they truly have"18. This sounds to me rather ambiguous: is it a careful attempt of reconciliation between Borgatta's financial-economic studies and Pareto's harsh judgements on economic methodology applied to public finance, or is it the germ of a Paretian heresy?

At any rate, no heresy may concern Sensini; it is suggested here that his inner coherence is granted since he considered at least part of his work in public finance as applied economics: see, for example, §29 in Sensini (1930).

Finally, Fasiani must be mentioned here because even if he did not belong to the sociological school, his general scientific methodology was Paretian; in fact, he stated a clear separation between science, politics and morals, negating any scientific value to value judgements as regards economic phenomena and institutions (Fasiani, 1949b, p. 67). Specifically in his Principii di Scienza delle Finanze (Fasiani, 1941), he contributed a general theory of public finance that incorporates some Pareto constructs,

\footnotetext{
${ }^{17}$ Moreover, he also stated: "even if it is given that the political phenomenon has ends and effects which are outside the economic hypothesis... and that financial activity has to be connected not to economic equilibrium, but to the sociological one... in the science, a crucial step...is to have determined in a rigorous manner the economic postulates" (Borgatta, 1934, p. XX, italics added).

18 Borgatta, Economia dinamica, Appendice, pp. 473-75 (quoted from Scotto, 1950, pp. 457-58).
} 
for example, the definition of his polar cases of State is based on the Paretian maximum utility "for" and "of" the community. He grasped the ideas of non-logical action, of residue and of derivation, and used them as a general framework, merged with Puviani's financial illusions. Still, his analysis remained within the field of economics, even if he abandoned the traditional concept of public need, accepting Barone's tautological definition of public need insofar as it is satisfied by a public subject. Thus, the final remark is that the sociological imprinting does not interfere with but actually enriches the economic treatment of Fasiani's scienza delle finanze.

Fasiani's Principii di Scienza delle Finanze may be considered to represent the highest point of evolution of the general theory of public finance in the Italian tradition, considering that from the assumption of polar cases of State, a number of logical developments follow, giving a unitary character to the whole analysis of the single aspects of public finance ${ }^{19}$.

\section{The influence of Paretian economic methodology}

An interesting point, which might be investigated, is that while Italian studies had some diffusion abroad, they scarcely influenced contemporary international thought. In particular, Pareto had no direct impact on Anglo-Saxon or continental scholars ${ }^{20}$; Pigou, for instance, apart from accepting from Pareto the term "ophelimity", maintained a hedonistic framework, developed the idea of externality (far from Pareto's economics) and considered the welfare of the community as a mere sum of individual

\footnotetext{
${ }^{19}$ On this matter, see Fossati (2009).

${ }^{20}$ Suffice it to remember the negative comments of Wicksell's review article about Pareto's Manuel: see McLure, 2007, pp. 39-40, or Irving Fisher's review of the Cours in The Yale Review, November 1896: see the letter that Pareto wrote to Fisher on December 9th, 1896 (De Rosa, 1960, Vol. III, pp.408-411).
} 
utilities $^{21}$. As is well known, the Paretian methodological approach was received later, through Hicks and Allen, and in the New Welfare Economics there is no sum of individual utilities.

On the contrary, it is argued here that Pareto did make quite an important mark on the Italian tradition of public finance, that is to say, the spreading of Pareto's economic methodology. In fact, it does not seem possible to doubt that Pareto greatly influenced the methodology of the Italian economic scholars who worked just before or after World War I. Thus, within the limits in which public finance scholars used marginal analysis, it is correct to state that Pareto was decisive as far as the methodology developed by the late Italian tradition. As an indicator, suffice it to consider the almost universal use by the young scholars of the Paretian term "ophelimity" instead of "utility", even if it could hide a tendency to assume exterior Paretian characteristics only. Actually, that tendency caused a reaction: see Jannaccone's article (Jannaccone, 1912), which was certainly unfair ${ }^{22}$, since it "presented Pareto's main followers, making specific reference to Sensini, Murray, Luigi Amoroso and Enrico Barone, as mere buffoons and mimics" (McLure, 2007, p. 11). Perhaps Jannaccone was the spokesperson of none, but surely he was quite near to Einaudi and the "literary economists", and, on this question, also to Pantaleoni, Graziani and Flora.

Within the Paretian economic methodological message, let's first consider the general equilibrium approach. Apparently, it was not widely adopted; only Sensini ventured to use the full formal apparatus, in particular when he included taxation in the Paretian equations of general equilibrium (Sensini, 1920 and 1930).

\footnotetext{
${ }^{21}$ On that point, see McLure (2009).

${ }^{22}$ However, some other questions were probably involved: see Fossati (2009). On Jannaccone's article, see Magnani (2005).
} 
Nevertheless, the idea of interdependence between markets was well understood by some scholars, albeit with no mathematics, so that it characterized one of the most important topics of the Italian tradition. The reference is to the analysis of the effects of taxation, which on the one hand included considering public expenditure, and on the other the repercussions in the other markets. De Viti de Marco was the first to consider systematically such scenarios ${ }^{23}$, but the topics extensively interested many scholars, debating the dilemma of accepting the abstract principle of interdependence, or continuing with the more viable Marshallian equilibrium and the hail-tax assumption. ${ }^{24}$

Secondly, independently of the use of the Paretian term "ophelimity", the distinction between utility and ophelimity was positively accepted, in the sense that those ambiguities which characterized the notion of utility were eliminated.

Thirdly, the idea of successive approximations and withinperiod adjustments leading to the final equilibrium in compared statics were accepted in principle by many: Fasiani, for one, ventured to proceed along that path with some achievements worthy of note. ${ }^{25}$

Finally, it is to be mentioned that the Paretian specification of the choice theory was generally accepted. That is to say, his idea of consumer equilibrium in terms of tastes and obstacles, and the correspondent graphical representation using ordinal indifference curves, became the standard. It is fair to note, however, that even if an aprioristic assumption of hedonistic utility function was

\footnotetext{
${ }^{23}$ See Fasiani (1943b, p.261 and 263) and Fossati (2009).

${ }^{24}$ See, for instance, Fasiani (1943b).

${ }^{25}$ For example, see Fasiani (1929).
} 
implicitly refused, probably they did not care much about the idea of revealed preference when drawing indifference curves.

On the other hand, I would not say that the idea of economic efficiency and the correspondent welfare theorems were fully understood in general, apart from the naïve notion that competitive market is better than monopoly. For instance, Einaudi's idea of optimal taxation is quite different from the modern notion of efficient taxation. The outstanding exception, of course, is Enrico Barone: suffice it to mention his Ministro della produzione nello stato collettivista (1908), or his 1912 theorem on the excess burden of indirect taxation ${ }^{26}$. Besides that, Fasiani draws attention to the fact that Barone $^{27}$ used a Paretian artefact, i.e., the Pareto law of income distribution, in order to suggest a distributive principle of taxation (Fasiani, 1949, p. 273 ff.). In fact, under the label of (efficient) "economic principle" of taxation, Barone recommends the system of taxation that lowers the growth of average national income as little as possible. The rationale is based upon Pareto's law of income distribution in the sense that from that law it follows that the rise in the average national income entails both a rise in minimum income and a better income distribution. In the words of Barone: "only through the rise in average income...one, the other, or both the following effects may take place: a simultaneous rise in all the incomes, or some individuals move from a lower to a higher income" (Barone, 1911-1912, p.46). Fasiani notes that "the choice of [that] principle [of taxation]... is not 'scientific'. However logical...this choice is nevertheless due to sentiments, judgements, desires that necessarily belong outside the field of logicoexperimental research". From that, he concludes that Barone used

\footnotetext{
${ }^{26}$ Barone (1912). The theorem had no direct impact on Anglo-Saxon scholars, since it was rediscovered only 27 years later in Joseph (1939).

27 Another principle of distribution of the tax burden, based on Pareto's law, is suggested by Crosara: see Fasiani (1949, pp. 274-275).
} 
the Paretian construct in a manner "strangely in contrast with the teachings of its discoverer" (Fasiani, 1949, p. 275).

This critique seems to me farfetched: it is true that Barone's taxation principle apparently depends on the value judgement that a more equitable income distribution is to be preferred to a less equitable one but, in fact, the principle is directed to carrying out a Paretian optimum. Were Pareto law true, the rise in the average income would entail growth in the utility level of one or more individuals, while no individual utility drops, because either all incomes rise or some low incomes rise: see Barone's quotation above. However, this is a definition of the Pareto optimum: hence Barone's taxation principle does not depend on value judgements, and is well inside the Paretian logico-experimental science. It is not satisfactory only because Pareto's income distribution law did not stand statistical evidence ${ }^{28}$.

Finally, it is fair to recall here that Fasiani used economic efficiency to define his polar case of Cooperative State, because its political elite is aimed at reaching a Paretian maximum for the community. In other words, the political elite points towards reaching efficient economic equilibria exclusively, and this fact makes Fasiani's definition of Cooperative State crucially different from De Viti's.

\section{Some final remarks}

The first remark regards Fasiani's 1949 article; it is fair to conclude that his analysis passed the test of time fairly well,

\footnotetext{
${ }^{28}$ The point is not the negative exponential form of the distribution, but the fact that the distribution is not helpful in the matter of income redistributive policies, both owing to the assumed constancy of its parameters and because - according to Pareto himself - it is valid for the higher tail of the income distribution only. I am grateful to Aldo Montesano for highlighting this point.
} 
because his main reasoning still stands. In general, what he observed twenty-five years after Pareto's death is still stimulating a further sixty years on. The main point that could be made concerns Pareto's law of income distribution, which would not be given much space now, because statistical evidence showed that it is not helpful in the matter of income redistributive policies. Still, in reconsidering Pareto's contributions to public finance, now we are not so keen to give prominence to his methodological suggestions for using sociological constructs. It is now quite evident that the great expectations founded on Paretian sociology were disappointed; accordingly, it might seem that Fasiani gave too much importance to that side of Pareto's message: on this point we are now at some variance with Fasiani.

The second remark is that Pareto's opposition to the scienza delle finanze was grounded on two different reasons: the central one was that a large part of its problems regards non-logical actions; such problems cannot be tackled with economic methodology since they are sociological problems. However, there is a second reason: some public finance problems are really applied economic problems in the Paretian sense. Thus, in a strict Paretian approach, some public finance problems may be considered, even if under the label of applied economics. This reasoning enables us to acknowledge a coherent Paretian inspiration not only in the applied research of Borgatta and Sensini, but even in that of other scholars usually not considered part of the sociological school, such as Barone and Fasiani.

As a third remark it seems important to point out that Fasiani's research programme was characterized by a dual effort, one part in the usual direction of using economic assumptions to explain specific public finance topics, and the other directed to offering a general and unitary explanation of the public choices, i.e., a general theory of public finance. As regards the latter, Fasiani 
was able to present a non-hedonistic version of the initial De Viti approach which represents, from that angle, the highest point of evolution of the general theory of public finance in the Italian tradition. Such an attempt is characterized by a definite Paretian mark, even if the sociological imprinting does not interfere with but actually enriches the economic treatment of Mauro Fasiani's public finance.

The fourth remark is that, before Pareto, some authoritative scholars were still convinced that moral values and value judgements were part of their scientific approach. On the contrary, Pareto's general methodology called for clear principles, related to facts, while any value judgement may concern only the aptitude of the means to reach a proposed end. Thus, Pareto's methodology appears to have deeply influenced the late Italian tradition in public finance. From the specifically economic angle, Pareto did make quite an important mark on the late scholars of the Italian tradition of public finance: suffice it to recall the general equilibrium approach that marked the analysis of the effects of taxation, considering both public expenditure, and the repercussion on the other markets. But also the idea of ophelimity was positively accepted, at least in the sense that those ambiguities which characterized the notion of utility were eliminated. Then, the idea of consumer equilibrium in terms of tastes and obstacles and the correspondent graphical representation using ordinal indifference curves became the standard, and the notion of successive approximations and within-period adjustments leading to the final equilibrium in compared statics were accepted in principle. On the other hand, the idea of economic efficiency was clearly accepted, at least by Barone and Fasiani.

The last remark regards Pareto in the present: it seems right to wonder about the message, if any, that Pareto may still address to the current public finance theory. Firstly, I would like to point 
out that for Pareto public action is redistributive only, while for the mainstream public finance theorists it was aimed at the production of public goods. At present, the redistributive function is largely prominent in modern states.

Secondly, Pareto considered it a fact that the governing classes had predatory attitudes in their redistributive action, even if democratic procedures were followed regarding public choices. At present, the political efficiency of democratic procedures depends largely on the specific social context but voting procedures are open to scientific investigation not only as regards their information requirements, but also in respect of the necessary context of rationality.

Pareto's distinction between logical and non-logical actions did not stand up to criticism, nevertheless, his basic idea that political choices are not only dependent on logic but on sentiments still seems worthy of our attention. Thus, it now seems reasonable to assert that a (positive) general theory of public choices cannot be based on economic assumption only, while the assumptions (both in a positive and normative context) might be posed only to the extent that they comply with the facts. This is, however, the core of the Paretian message.

\section{Acknowledments}

I am grateful to Domenicantonio Fausto, Francesco Forte, Emilio Gerelli, Emilio Giardina, Michael McLure and Aldo Montesano for their comments on earlier versions of this paper. This article was presented to the PGPPE Conference, Istanbul, June 25-27, 2010. I am indebted to the participants of the conference, even if any remaining shortcomings are my own responsibility. 


\section{References}

Barone, Enrico, 1908, "Il ministro della produzione nello stato collettivista", in Giornale degli economisti e Rivista di statistica, Sept. pp.267-293 and Oct. pp.391-414.

Barone, Enrico, 1911-12, Scienza delle Finanze, reprinted in Le opere economiche, vol. III, Principi di Economia finanziaria, Bologna: Zanichelli, 1937.

Barone, Enrico, 1912, "Studi di economia finanziaria", in Giornale degli economisti, reprinted in Barone (1911-12), pp.38-42.

Borgatta, Gino, 1912a, I problemi fondamentali della scienza finanziaria, in "Atti della R. Accademia delle scienze di Torino", pp. 985-1007.

Borgatta, Gino, 1920, L'economia dinamica. Saggi sui problemi dinamici nell'economia pura, Torino, UTET, 1920. The first edition had a limited circulation with the title L'economia dinamica. Studio critico su problemi dinamici nell'economia pura, Torino, UTET, 1915.

Borgatta, Gino, 1920, "Lo studio scientifico dei fenomeni finanziari", in Giornale degli economisti e Rivista di statistica, 31 (60), pp.1-24 and 81-116.

Borgatta, Gino, 1934, Prefazione, in Borgatta, Gino (Ed.), "Finanza", Nuova collana di economisti, Volume IX, Torino: Utet.

Da Empoli, Domenico, 2001, Vilfredo Pareto e la scienza delle finanze, in Busino, G. (Ed.), Pareto oggi, Bologna: Il Mulino, 2001, pp. 143146.

De Rosa, Gabriele, 1960 (Ed.) Vilfredo Pareto. Lettere a Maffeo Pantaleoni, Vol. I, II, III, Roma: Banca Nazionale del Lavoro.

De Viti de Marco, Antonio, 1888, Il carattere teorico dell'Economia Finanziaria. Roma: Loreto Pasqualucci editore.

Einaudi, Luigi, 1943a, Ipotesi astratte ed ipotesi storiche e dei giudizi di valore nelle scienze economiche, Torino, $\mathrm{R}$. Accademia delle Scienze.

Fasiani, Mauro, 1929, "Elementi per una teoria della durata del processo traslativo dell'imposta in una società statica", in Giornale degli economisti e Rivista di statistica, August, pp. 557-83, and September, pp. 687-714. English translation as: "Theory of the Duration of the Process of Tax shifting", in Review of Economic studies, Vol. I, 19331934, February, pp. 81-101, e Vol. II, 1934-1935, February, pp. 12237 
Fasiani, Mauro, 1932-33, „Der gegenwärtige Stand der reine Theorie der Finanzwissenschaft in Italien“, parts I, II and III, in Zeitschrift für Nationalökonomie, Band III, Heft 5, pp. 651-91; Band IV, Heft 1, pp. 79-107; band IV, Heft 3, pp. 357-88.

Fasiani, Mauro, 1941, Principii di Scienza delle Finanze, vol. I \& II, Torino, Giappichelli. $2^{\text {nd }}$ edition: 1951

Fasiani, Mauro, 1943b, "Sulla legittimità dell'ipotesi di un'impostagrandine nello studio della ripercussione dei tributi", in Studi in memoria di Guglielmo Masci, Milano: Giuffrè, Vol. I, pp.261-279.

Fasiani, Mauro, 1949, "Contributi di Pareto alla Scienza delle Finanze", in Giornale degli Economisti e Annali di Economia, n. 3-4, pp. 129173. English translation as Pareto's Contributions to the Science of Public Finance, in McLure (2007), pp. 266-305.

Fossati, Amedeo, 2009, Pareto and Italian public finance scholars in the first half of the XX century, mimeo.

Griziotti, Benvenuto, 1943, "Sugli effetti dei prestiti e delle imposte e sulla scienza delle finanze (lettere al Prof. Benvenuto Griziotti)", in Giornale degli economisti e Annali di economia, pp.133-140.

Jannaccone, Pasquale, 1912, "Il Paretaio", in "La riforma sociale", n.5, pp.337-338.

Joseph, M., 1939, “The excess burden of indirect taxation", in Review of economic studies,

Magnani, Italo, 2005, "Il "Paretaio"”, Economia politica, April, pp.69100.

McLure, Michael, 2007, The Paretian School and Italian Fiscal Sociology, Houndmills and New York: Palgrave Macmillan.

McLure, Michael, 2009, Pareto and Pigou on Ophelimity, Utility and Welfare: Implication for Public Finance, mimeo.

Myrdal, Gunnar, 1932, Das Politische Element in der Nationalökonomischen Doktrinbildung, Berlin: Junker und Dünnhaupt. Italian translation as L'elemento politico nella formazione delle dottrine dell'economia pura, Firenze: Sansoni, 1943.

Pareto, Vilfredo, 1896-1897, Cours d'Ėconomie politique, Lausanne: F. Rouge.

Pareto, Vilfredo, 1902-1903, Les Systèmes Socialistes, Giard \& Brière, reprinted in Oevres complètes, V, edited by G.Busino, Librairie Droz: Genève, 1965. 
Pareto, Vilfredo, 1906, Manuale di economia politica, Padova: CEDAM. Quotations from the critical edition V.Pareto, Manuale di economia politica, A.Montesano-A.Zanni-L.Bruni (Editors), Milano: EGEA Università Bocconi, 2006.

Pareto, Vilfredo, 1909, Manuel d'Économie Politique,, Paris: Giard and Brière. Quotations from the critical edition V.Pareto, Manuale di economia politica, A.Montesano-A.Zanni-L.Bruni (Editors), Milano: EGEA Università Bocconi, 2006.

Pareto, Vilfredo, 1913, "Il massimo di utilità per una collettività in sociologia", in Giornale degli economisti e Rivista di statistica, pp. 337-41.

Pareto, Vilfredo, 1916, Trattato di Sociologia generale, Vol. I and II, Firenze: Barbèra

Robbins, Lionel, 1932, An essay on the nature and significance of Economic Science, London: Macmillan.

Scotto, Aldo, 1950, "L'opera scientifica di Gino Borgatta", in Giornale degli economisti e Annali di economia, anno IX (nuova serie) Fasc.9-10, pp.441-506.

Sensini, Guido, 1920, "Le equazioni dell'equilibrio economicofinanziario, per un punto dato, nel caso delle imposte e in un regime di concorrenza economica", in Rivista italiana di sociologia, OctoberDecember.

Sensini, Guido, 1930, "Le equazioni dell'equilibrio economico nell'ipotesi di sottrazioni di ricchezza operate dal governo su determinati individui della collettività", in Giornale degli economisti e Rivista di statistica, 45(70), pp.689-709.

Sensini, Guido, 1948, Corrispondenza di Vilfredo Pareto, Padova: Cedam. 